\title{
History of myopia research in Szczecin after World War II
}

\author{
Damian A. Czepita ${ }^{1}$, Aleksandra Kładna ${ }^{2}$ \\ ${ }^{1}$ Foreign Language Department, Pomeranian Medical University, Szczecin, Poland \\ ${ }^{2}$ Department of the History of Medicine and Medical Ethics, Pomeranian Medical University, Szczecin, Poland
}

\begin{abstract}
In the conducted examinations we determined that the leading center in myopia research after World War II in Poland is the Pomeranian Medical Academy (Pomeranian Medical University). In Szczecin after the World War II, various areas of ophthalmology developed significantly. Particularly intense development occurred in the field of myopia. In the conducted studies, attention was paid to epidemiology, clinical trials, surgical and conservative treatment, as well as the publication of review articles on myopia. The research findings of scientists from Szczecin were published all over the world in many prestigious journals. Their works were mostly known in the field of myopia occurrence, as well as surgical and conservative myopia treatment. The results obtained allowed the development of new methods of myopia management. The Pomeranian Medical Academy (Pomeranian Medical University) was the leading center in Poland conducting research on myopia. The researchers working in this center dealt with epidemiology, pathogenesis as well as the possibilities of surgical and conservative myopia treatment. They also pointed to the potential of using the results of experimental studies in the treatment of progressive myopia. Based on the scientific achievements of researchers of the Polish medical community after World War II, it can be assumed that in the future, scientific research will focus on the pathogenesis and treatment of myopia. The doctors place great hope on genetic treatment in inhibiting myopia progression.
\end{abstract}

KEY WORDS: myopia, history, Szczecin

Ophthalmol J 2018; Vol. 3, No. 1, 8-13

\section{INTRODUCION}

Myopia is more and more common, but so far no effective treatment for this refractive error has been developed. Only a few methods of myopia treatment have been described.

The word "miopia" derives from Greek and means closing of the eyelids or squinting. These activities lead to the creation of a small hole between the eyelids (a pin-hole effect) and a temporary improvement in vision among people with myopia. This method was already known to the ancient Greeks.

Although information regarding myopia can already be found in ancient texts, no article on the history of myopia research in Szczecin after World
War II has yet been published [1-7]. Therefore, the aim of the work is to present the history of research on myopia in Szczecin after World War II. In order to obtain answers to the research questions posed, studies of source and archival materials were conducted. To achieve the goal of the work, the following research questions were posed:

1. What was the history of research on myopia in Szczecin after World War II?

2. What was the influence of the achievements of doctors from Szczecin on the development of myopia research after World War II?

3. What was the contribution of the Pomeranian Medical Academy (Pomeranian Medical University) in the study of myopia after the Second World War? 


\section{MATERIALS}

An inquiry was made in the archive of: the $\mathrm{Li}$ brary of the Ophthalmology Chair and Clinic of the Pomeranian Medical University in Szczecin, the Pomeranian Library in Szczecin, the Pedagogical Library in Szczecin and the Department of the History of Medicine and Medical Ethics of the Pomeranian Medical University.

A complete bibliography of scientific achievements of researchers from Szczecin in the field of myopia after World War II was collected [1-62], the achievements were subjected to detailed analysis and were compared with the current state of knowledge. The chronological and material methods were applied. Authorized surveys were also carried out.

\section{RESULTS \\ EPIDEMIOLOGICAL RESEARCH}

Epidemiological research on myopia was initiated in 1972 by Mikulski from the Pomeranian Medical Academy [50]. He analyzed the prevalence and progression of refractive errors among the 752 people that he treated in Kamień Pomorski. Mikulski stated that uncorrected myopia can turn into myopic anisometropy

Epidemiological research in Szczecin was continued by Baranowska-George et al. from the Pomeranian Medical Academy [13, 14]. The authors examined children from 6 to 16 years of age and showed that there was a sharp increase in the incidence of myopia. In addition, they pointed to the need to use cycloplegia when choosing glasses due to the coexisting accommodation spasm.

Mozolewska-Piotrowska et al. from the Pomeranian Medical Academy [52] observed an almost two-fold increase in the prevalence of myopia among students of the Faculty of Medicine and Dentistry of the Pomeranian Medical University in Szczecin.

The widest research on myopia since 1995 was conducted by Czepita D. et al. from the Pomeranian Medical Academy (Pomeranian Medical University). Almost 6000 people were examined. Based on the tests carried out, it was found that:

- Myopia is observed in 3.3\% of 7 and 8 year old children and in $13.3 \%$ of school-aged children. There is a positive correlation between myopia and age.

- Myopia is more common in girls (7.4\%) than in boys (5.1\%).
- Myopia is more common in children living in a city than in rural areas $[21,24,25,28,29,31,33]$.

\section{CLINICAL STUDIES}

In 1978, Andrzejewska et al. from the Pomeranian Medical Academy [11] found that people with myopia over $-10 \mathrm{D}$ had a very wide or wide iridocorneal angle, with a small amount of pigment. The mean intraocular pressure values for them did not exceed $20 \mathrm{mmHg}$. Administration of $2 \%$ pilocarpine did not affect the intraocular pressure, while administration of $10 \%$ neosynephrine reduced the intraocular pressure. The outflow coefficient was within normal limits. Pilocarpine and neosynephrine led to its growth

In the 1980s, Sylwestrzak and Koronczewska from the Myopic Children's Outpatient Clinic [61] found that exophoria often occurs in children with myopia. However, Karczewicz from the Pomeranian Medical Academy [42] observed that in the eyes with myopia the arterial-venous ratio increases, depending on how big the refractive error is and the axial length of the eyeball. She also stated that in myopia the mean Doppler frequency of the ciliary body, retinal vessels and choroidal vessels is reduced.

20 years later new diagnostic possibilities appeared - such as the color Doppler ultrasound. Therefore, Karczewicz and Modrzejewska from the Pomeranian Medical Academy [44, 45] were able to confirm their results and showed that in people with high myopia there is a decrease in the blood flow of the eyeball vessels and the central retinal artery.

Modrzejewska et al. from the Pomeranian Medical University [51] after examining premature infants with no pre-retinopathy, found that the eyeballs of people with myopia were longer and that hyperopia was positively correlated with birth weight.

In the conducted studies, Czepita D. et al. from the Pomeranian Medical Academy (Pomeranian Medical University) showed that:

- Sleeping up to the age of 2 in an illuminated area leads to more frequent myopia.

- Genetic factors have a wide influence on the occurrence of myopia.

- Environmental factors such as reading, writing, and visual work on the computer can lead to myopia. However, watching TV does not affect the occurrence of myopia.

- HLA class II antigen determination may be an auxiliary diagnostic and prognostic indicator in people with high myopia. 
- Low and medium myopia can lead to significant changes in the visual field.

- In the course of myopia, the radius of cornea curvature is reduced. In contrast, corneal astigmatism predisposes to the progression of myopia [17-20, 22, 23, 26, 27, 36, 40, 62].

In 2015, Czepita M. et al. from the Pomeranian Medical University [39] after testing 70 people with a dynamic contour tonometer, showed that the ophthalmic amplitude (OPA) decreases with the increase in the axial length of the eyeball and a decrease in the spherical equivalent. An increase in intraocular pressure leads to a drop in the amplitude of the ocular pulse.

\section{SURGICAL TREATMENT}

In 1965, Starkiewicz from the Pomeranian Medical Academy [59] (Fig. 1) introduced a surgery to band the eyeball with the patient's own deep fascia of the thigh to strengthen the posterior pole of the eye with high myopia. He described this procedure in "Klinika Oczna" and called it "circumligatio meridionalis".

Initial results were very promising. In 1967, Starkiewicz and Markiewicz-Jabłońska from the Pomeranian Medical Academy [60] conducted an

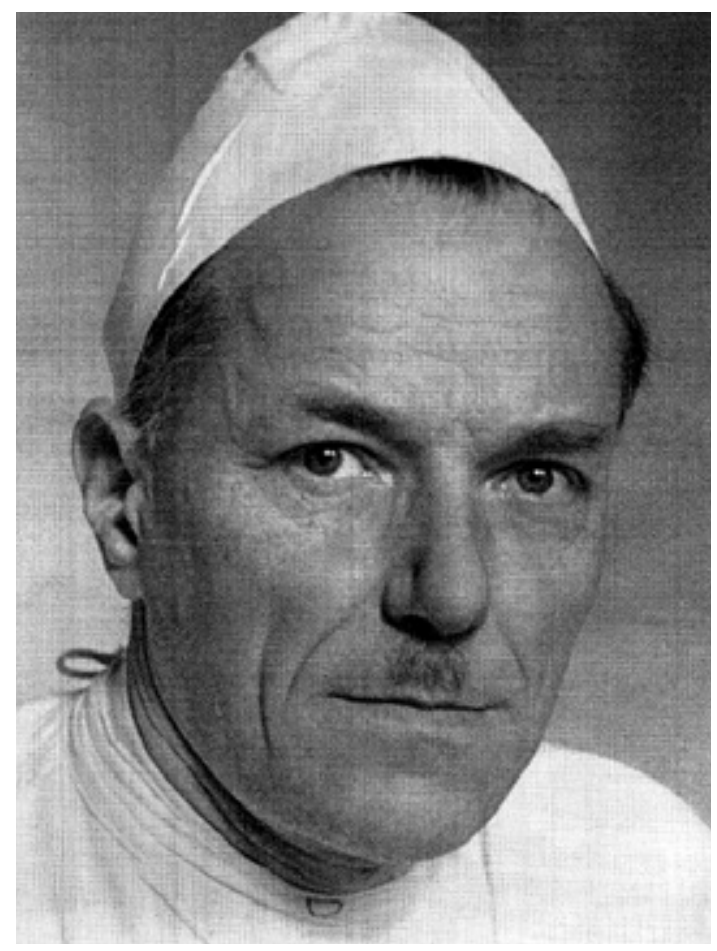

FIGURE 1. Professor Witold Starkiewicz

Source: Library of the Ophthalmology Chair and Clinic of the Pomeranian Medical University analysis of 72 operations. The authors showed that three patients had complications in the form of serum exudate in the anterior chamber and the vitreous, retinal detachment, changes in the macula and conjunctival cyst.

In 1972, Andrzejewska from the Pomeranian Medical Academy [8] re-analyzed the results of treatment with the "circumligatio meridionalis" method. In the years from 1967 to 1970 , out of the 74 operated eyes there were two direct surgical complications: in one case - a large swelling of the eyelids with symptoms of tenonitis occurred in the second case - hyphema, exudative choroiditis with retinal detachment occurred. In the discussion, the author stated that "circumligatio meridionalis" inhibits the growth of the refractive error, which indicates a positive treatment outcome.

In 1979, Andrzejewska and Karczewicz from the Pomeranian Medical Academy [9] evaluated the indications for "circumligatio meridionalis" in high-myopia. The authors decided that not only should the value of the refractive error be evaluated, but the lack or appearance of destructive lesions of the fundus, the general condition of the child and the family history should all be assessed when making an operative decision.

In 1987, Andrzejewska et al. from the Pomeranian Medical Academy [10] conducted another analysis of the treatment results of "circumligatio meridionalis". The authors stated that "with the operating technique we used, we were unable to effectively stop the progress of the refractive error in all the operated eyes. We only got a slight advantage in stabilizing the refractive error in the operated eyes than in the eyes which were not operated on."

\section{CONSERVATIVE TREATMENT}

In the 1970s, the Chair and Clinic of Ophthalmology at the Pomeranian Medical Academy in Szczecin began conservative treatment of degenerative changes of the retina in the course of high myopia.

Initially, treatment with ETO was carried out. ETO is an extract of the eyeball, which increases the regeneration processes, modifies circulation and the metabolism of the body. ETO was administered subconjunctivaly. Improvement in visual acuity, visual field and electroretinographic recordings was achieved [48].

In 1979 Kozielec from the Pomeranian Medical Academy [47] published a work in which she proved that intravenous administration of vitamin 
PP improves the sharpness and field of vision in people with high myopia. The obtained results were confirmed by the electroretinographic examinations of Palacz and Kozielec from the Pomeranian Medical Academy [54].

In 1987, Andrzejewska et al. from the Pomeranian Medical Academy [10] have shown that the treatment of patients with high myopia using ETO, FIBS, vitamin $\mathrm{PP}, \mathrm{B}_{1}, \mathrm{~B}_{12}$ stabilizes visual acuity, field of vision and the fundus.

The center in Szczecin popularized exercises in Poland with positive power lenses in accommodative myopia. Treatment with this method was conducted by Baranowska-George et al. from the Pomeranian Medical Academy [15], Karczewicz et al. from the Pomeranian Medical Academy [43], Koronczewska and Sylwestrzak from the Myopic Children's Outpatient Clinic [46]. The exercises reduced the accommodation spasm and improved visual acuity. A significant improvement was obtained in cases of accommodation spasm resulting from stress.

In 2005 Puchalska-Niedbał and Baranowska-George from the Pomeranian Medical Academy [57] observed that treatment with vitamin $B_{1}$ and exercises with glasses $-3 \mathrm{D}$ improve accomodation.

A new and effective method of treating myopia was introduced by Puchalska-Niedbał and Sylwestrzak from the Pomeranian Medical University [58]. The authors showed that magnetotherapy improves and stabilizes vision in patients with degenerative myopia.

\section{REVIEW PAPERS}

Many of the review papers on myopia were published by Czepita from the Pomeranian Medical Academy (Pomeranian Medical University) [1-7]. In his articles he discussed contemporary views on aetiology, epidemiology, pathogenesis and treatment of school and progressive myopia. Czepita pointed to the possibility of using the results of the latest experimental studies in the treatment of progressive myopia.

The scientific achievements of Starkiewicz were described in a doctoral thesis by Lipiński from the Pomeranian Medical Academy [49].

In 2013, Puchalska-Niedbat from the Pomeranian Medical University [56] described and discussed the current state of knowledge on accommodation.

In 2017, Czepita M. and Czepita D. from the Pomeranian Medical University [37] and Czepita M. et al. from the Pomeranian Medical University [38] wrote two papers on the subject of the prevalence of myopia in Poland.

In 2018, Grudzińska and Modrzejewska from the Pomeranian Medical University [51] published a review of studies assessing ocular blood flow in myopes.

\section{CONCLUSIONS}

The leading center in myopia research after World War II in Poland is the Pomeranian Medical Academy (Pomeranian Medical University).

In Szczecin after the Second World War, various areas of ophthalmology developed significantly. Particularly intense development occurred in the field of myopia. In the conducted studies, attention was paid to epidemiology, clinical trials, surgical and conservative treatment as well as the publication of review articles on myopia.

The research findings of scientists from Szczecin were published all over the world in many prestigious journals. Their works were most known in the field of myopia occurrence as well as surgical and conservative myopia treatment. The results obtained allowed the development of new methods of myopia management.

The Pomeranian Medical Academy (Pomeranian Medical University) in Szczecin was the leading center in Poland conducting research on myopia. The researchers working in this center dealt with epidemiology, pathogenesis as well as the possibilities of surgical and conservative myopia treatment. They also pointed to the potential of using the results of experimental studies in the treatment of progressive myopia.

Based on the scientific achievements of researchers of the Polish medical community after World War II, it can be assumed that in the future scientific research will focus on the pathogenesis and treatment of myopia. The doctors place great hope on genetic treatment in inhibiting myopia progression.

\section{REFERENCES}

1. Czepita D. Możliwości wykorzystania wyników najnowszych badań doświadczalnych w leczeniu krótkowzroczności postępującej. Klin Oczna. 199; 101: 145-147.

2. Czepita D. Wspótczesne poglądy na etiologię, patogenezę oraz leczenie krótkowzroczności szkolnej i postępującej. Klin Oczna. 1999; 101: 477-480.

3. Czepita D. Myopia - epidemiology, pathogenesis, present and coming possibilities of treatment. Case Rep Clin Pract Rev 2002; 3 ; 294: 300.

4. Czepita D. Podstawy nowoczesnego leczenia krótkowzroczności. Ann Acad Med Stetin. 2005; 51(2): 5-9.

5. Czepita D. Wady refrakcji. Lekarz. 2007; 11(1-2): 46-49.

6. Czepita D. Myopia - incidence, pathogenesis, management and new possibilities of treatment. Russ Ophthalmol J. 2014; 7(1): 96-101. 
7. Czepita D, Żejmo M, Czepita DA, et al. Krótkowzroczność - epidemiologia, patogeneza, postępowanie. Okulistyka. 2013; 16: 74-78.

8. Andrzejewska W. Dalsze wyniki leczenia postępującej krótkowzroczności za pomocą circumligatio meridionalis. Klin Oczna. 1972; 42: 263-268.

9. Andrzejewska W, Karczewicz D. Wskazania do zabiegu circumligatio meridionalis w krótkowzroczności wysokiej. Klin Oczna. 1979; 81: 359-361.

10. Andrzejewska W, Karczewicz D, Lisicka E, et al. Późne wyniki leczenia krótkowzroczności wysokiej postępującej za pomocą circumligatio meridionalis. I. Refrakcja, ostrość wzroku, dno oka. Klin Oczna. 1987; 89: $347-350$.

11. Andrzejewska W, Remlein-Mozolewska G, Kozielec J. Ocena morfologiczna i czynnościowa kąta tęczówkowo-rogówkowego u osób z krótkowzrocznością wysoką. Klin Oczna. 1978; 48: 259-261.

12. Andrzejewska W, Tokarz-Sawińska E, Stankiewicz W, et al. Wyniki leczenia zachowawczego krótkowzroczności wysokiej u dzieci. Klin Oczna. 1987; 89: 341-343.

13. Baranowska-George T, Koronczewska D, Sylwestrzak Z. Charakterystyka krótkowzroczności wieku szkolnego na podstawie materiału Poradni dla Dzieci Krótkowzrocznych. I. Wielkość wadyi skurcz akomodacji. Klin Oczna 1987. ; 89: 333-336.

14. Baranowska-George T, Koronczewska D, Sylwestrzak Z. Charakterystyka krótkowzroczności wieku szkolnego na podstawie materiału Poradni dla Dzieci Krótkowzrocznych. II. Zagadnienie dziedziczności. Klin Oczna 1987; 89. ; 337: 338.

15. Baranowska-George T, Łąk D, Kwietniak V. Leczenie krótkowzroczności akomodacyjnej - doniesienie wstępne. Klin Oczna. 1994; 96: 322-323.

16. Baranowska-George T, Puchalska-Niedbał L, Modrzejewska M. Metoda leczenia patologicznego skurczu akomodacji wywołanego stresem opracowana w Przychodni Przyklinicznej Katedry Okulistyki w Szczecinie - opis przypadków. Okulistyka. 2013; 16: 28-30.

17. Czepita D, Chmielewska I. Charakterystyka zmian w obrębie statycznego pola widzenia u osób z krótkowzrocznością małą i średnią. Ann Acad Med Stetin. 2004; 50(1): 21-24.

18. Czepita D, Filipiak D. Promień krzywizny rogówki u osób z krótkowzrocznością. Klin Oczna. 2003; 105: 155-156.

19. Czepita D, Filipiak D. Rola astygmatyzmu w powstawaniu krótkowzroczności. Klin Oczna. 2003; 105: 385-386.

20. Czepita D, Filipiak D. Wpływ formy astygmatyzmu na powstawanie krótkowzroczności. Klin Oczna. ; 107: 73-74.

21. Czepita D, Gosławski W, Mojsa A. Występownie krótkowzroczności wśród uczniów w wieku od 6 do 18 lat. Klin 0czna. 2003; 105: 52-56.

22. Czepita D, Gosławski W, Mojsa A, et al. Role of light emitted by incandescent or fluorescent lamps in the development of myopia and astigmatism. Med Sci Monit. 2004; 10: 168-171.

23. Czepita D, Mojsa A, Czepita M, et al. Myopia and night lighting. Investigations on children with negative family history. Klin Oczna. 2012; 114: 22-25.

24. Czepita D, Mojsa A, Ustianowska $M$, et al. Prevalence of refractive errors in schoolchildren ranging from 6 to 18 years of age. Ann Acad Med Stetin. 2007; 53(1): 53-56, indexed in Pubmed: 18561610.

25. Czepita D, Mojsa A, Ustianowska $M$, et al. Role of gender in the occurrence of refractive errors. Ann Acad Med Stetin. 2007; 53(2): 5-7, indexed in Pubmed: 18557370.

26. Czepita D, Mojsa A, Ustianowska M, et al. Reading, writing, working on a computer or watching television, and myopia. Klin Oczna. 2010; 112(10-12): 293-295, indexed in Pubmed: 21469524.

27. Czepita $D$, Mojsa $A$, Ustianowska $M$, et al. The effect of genetic factors on the occurrence of myopia. Klin Oczna. 2011; 113(1-3): 22-24, indexed in Pubmed: 21853945.

28. Czepita D, Mojsa A, Zejmo M. Prevalence of myopia and hyperopia among urban and rural schoolchildren in Poland. Ann Acad Med Stetin. 2008; 54(1): 17-21, indexed in Pubmed: 19127805.

29. Czepita D, Palacz 0. Występowanie wad refrakcji u uczniów w Polsce. Kontaktol Opt Okul. 2011; 2: 9-11.

30. Czepita D, Zejmo M. Analiza przyczyn inwalidztwa wzrokowego na podstawie opinii sądowo-lekarskich. Klin Oczna. 2005; 107: 300-303.

31. Czepita D, Zejmo M, Mojsa A. Prevalence of myopia and hyperopia in a population of Polish schoolchildren. Ophthalmic Physiol Opt. 2007;
27(1): 60-65, doi: 10.1111/j.1475-1313.2006.00419.x, indexed in Pubmed: 17239191.

32. Czepita DA. Education and myopia. Kontaktol Opt Okul. 2011; 2: 22-24.

33. Czepita DA. Refractive error prevalence among children in Poland. Kontaktol Opt Okul 2013; 4. ; 9: 10.

34. Czepita DA. Historia badań nad krótkowzrocznością w Polsce po II wojnie światowej. Praca na stopień doktora nauk o zdrowiu. PUM, Szczecin 2017: Szczecin.

35. Czepita DA, Łodygowska E. Higiena pracy wzrokowej. Lekarz. 2012; 15(3): 42-45.

36. Czepita DA, Zejmo M. Environmental factors and myopia. Ann Acad Med Stetin. 2011; 57(3): 88-92; discussion 92, indexed in Pubmed: 23383553.

37. Czepita M, Czepita D. Zachodniopomorskie badania epidemiologiczne ukierunkowane na wykrywanie krótkowzroczności. Okulistyka. 2017; 20: 20-21.

38. Czepita M, Czepita D, Lubiński W. The Influence of Environmental Factors on the Prevalence of Myopia in Poland. J Ophthalmol. 2017; 2017: 5983406, doi: 10.1155/2017/5983406, indexed in Pubmed: 29348929.

39. Czepita M, Karczewicz D, Safranow K, et al. Macular Pigment Optical Density and Ocular Pulse Amplitude in Subjects with Different Axial Lengths and Refractive Errors. Med Sci Monit. 2015; 21: 1716-1720, doi: 10.12659/MSM.893225, indexed in Pubmed: 26071973.

40. Czepita M, Safranow K, Czepita D. The influence of reading and writing on the prevalence of myopia. Ann Acad Med Stetin. 2014; 60(2): 34-36, indexed in Pubmed: 26591104.

41. Grudzińska E, Modrzejewska M. Modern Diagnostic Techniques for the Assessment of Ocular Blood Flow in Myopia: Current State of Knowledge. J Ophthalmol. 2018; 2018, doi: 10.1155/2018/4694789, indexed in Pubmed: 29607217.

42. Karczewicz D. Badanie układu naczyniowego w oczach z krótkowzrocznością wysoką. Ann Acad Med Stetin. 1987; 33: 229-259.

43. Karczewicz D, Adamek B, Kasprowska M, et al. Zastosowanie ćwiczeń ze szkłami plusowymi w profilaktyce krótkowzroczności szkolnej. In: Iwaszkiewicz-Bilikiewicz B. (ed): Współczesne zagadnienia okulistyki dziecięcej. Gdańsk. ; 1990: 114-119.

44. Karczewicz D, Modrzejewska M. Ocena przepływu krwi w naczyniach krwionośnych oka u osób z krótkowzrocznością. Klin Oczna. 2004; 106(1-2 Suppl): 211-213.

45. Karczewicz D, Modrzejewska M. Ocena przepływu krwi w naczyniach krwionośnych oka u osób z krótkowzrocznością i jaskrą pierwotną otwartego kąta. Klin Oczna. 2004; 106(1-2 Suppl): 214-216.

46. Koronczewska D, Sylwestrzak Z. Wpływ ćwiczeń z okularami plusowymi na stan wzroku krótkowidzów. Klin Oczna. 1987; 89: 344-346.

47. Kozielec J. Witamina PP w leczeniu zmian zwyrodnieniowych spowodowanych krótkowzrocznością wysoką. Klin Oczna. 1979; 81: 351-353.

48. Kozielec J, Remlein-Mozolewska GE. ETO w leczeniu zmian zwyrodnieniowych siatkówki spowodowanych krótkowzrocznością wysoką. Klin Oczna. 1976; 46: 1409-1414.

49. Lipiński A. Prof. dr hab. Witold Starkiewicz jako okulista i wspótorganizator Pomorskiej Akademii Medycznej. Praca na stopień doktora nauk medycznych. PUM, Szczecin 1997: Szczecin.

50. Mikulski T. Dynamika wad refrakcji oczu. Klin Oczna. 1972; 42: 389-393.

51. Modrzejewska M, Grzesiak W, Karczewicz D, et al. Refractive status and ocular axial length in preterm infants without retinopathy of prematurity with regard to birth weight and gestational age. J Perinat Med. 2010; 38(3): 327-331, doi: 10.1515/JPM.2010.018, indexed in Pubmed: 20121489.

52. Mozolewska-Piotrowska K, Stępniewska J, Nawrocka J. Występowanie krótkowzroczności szkolnej u studentów medycyny. Klin Oczna. 2005: 107: 468-470.

53. Palacz 0. Układ wzrokowy i jego podstawowa funkcja - proces widzenia. In: Palacz 0. ed. Okulistka współczesna. PZWL, Warszawa 1986: 9-99.

54. Palacz 0, Kozielec J. Przydatność preparatu ETO w leczeniu zmian zwyrodnieniowych siatkówki spowodowanych krótkowzrocznością wysoką w aspekcie badań elektrofizjologicznych. Klin Oczna. 1977; 47: $579-581$ 
55. Palacz 0, Kozielec J. Wyniki leczenia witaminą PP chorych z krótkowzrocznością wysoką w świetle badań elektroretinograficznych. Klin Oczna . 1979; 81: 355-357.

56. Puchalska-Niedbał L. Akomodacja - obecny stan wiedzy. Okulistyka. ; 25(16): 25-27.

57. Puchalska-Niedbał L, Baranowska-George T. Zaburzenie akomodacji jako przyczyna bólów głowy - doniesienie wstępne. Okulistyka . ; 61: 61-63.

58. Puchalska-Niedbał L, Sylwestrzak Z. Magnetostymulacja - metoda fizykoterapii stosowana w leczeniu ciężkich schorzeń narządu wzroku takich jak zwyrodnienie plamki związane z wiekiem i krótkowzroczność zwyrodnieniowa. Okulistyka . ; 17: 55-59.
59. Starkiewicz W. Circumligatio meridionalis. Nowy sposób operacyjnego leczenia postępującej krótkowzroczności. Klin Oczna. ; 35: 363-366.

60. Starkiewicz W, Markiewicz-Jabłońska E. Pierwsze wyniki leczenia postępującej krótkowzroczności za pomocą Circumligatio meridionalis. Klin Oczna . 1967; 37: 831-838.

61. Sylwestrzak Z, Koronczewska D. Stan równowagi mięśniowej u dzieci z krótkowzrocznością małego i średniego stopnia. Klin Oczna.; 89: $339-340$.

62. Zejmo M, Czepita D, Mikłaszewicz A, et al. Associations between high myopia and class II HLA. Acta Ophthalmol. 2010; 88(7): e281, doi: 10.1111/j.1755-3768.2009.01724.x, indexed in Pubmed: 20015101. 